\title{
Pemaknaan Konflik Pabrik Semen Kendeng dalam Framing Media Berita Online kompas.com dan suara merdeka.com
}

\author{
Mohammad Solihin dan Novi Kurnia \\ Mahasiswa Program S2 Ilmu Komunikasi FISIPOL Universitas Gadjah Mada \\ Email: mas.mohammadsolihin@gmail.com \\ Email: noniknovi@yahoo.com
}

\begin{abstract}
Citizens repellent resistance establishment of a cement factory in the district of Pati and Rembang, Central Java gets a different meaning by online news media. This research seeks to uncover the construction of national online news media kompas.com and local online news media of suaramerdeka.com in defining reality conflict Kendeng cement plant during 2015. The method used framing analysis Robert $M$. Entman models with an emphasis on elements define problem and diagnose cause. There are three categories used to see that framing the struggle for citizens Kendeng, the trial lawsuit Kendeng cement plants, and the role of Central Java Governor reducing conflict cement Kendeng. Of the three issues mentioned get the result that the national online news media kompas.com shows the position and their support is likely to deliver more dominant portion to one of the conflicting parties. While local online news media suaramerdeka. com relatively proportional in preaching the pros and cons of a cement factory Kendeng.
\end{abstract}

Keywords: Framing Analysis, Online News Media, Ideology, New Media, Conflict Cement Kendeng

\begin{abstract}
Abstrak
Perlawanan warga penolak pendirian pabrik semen di Kabupaten Pati dan Kabupaten Rembang, Jawa Tengah mendapat pemaknaan yang berbeda oleh media berita online. Penelitian ini berupaya untuk mengungkap konstruksi pemberitaan media berita online nasional kompas.com dan media berita online lokal suaramerdeka.com dalam memaknai realitas konflik pabrik semen kendeng selama tahun 2015. Metode yang digunakan analisis framing model Robert M. Entman dengan penekanan pada elemen define problem dan diagnose cause. Ada tiga kategori yang digunakan untuk melihat framing yaitu aksi perjuangan warga Kendeng, sidang gugatan pabrik semen kendeng, dan peran Gubernur Jawa Tengah meredam konflik semen kendeng. Dari ketiga isu tersebut didapatkan hasil bahwa media berita online nasional kompas.com menunjukkan posisi dan keberpihakannya yang cenderung memberikan porsi lebih dominan kepada salah satu pihak yang berkonflik. Sementara media berita online lokal suaramerdeka.comrelatifproporsionaldalammemberitakan pihak prodankontrapabriksemenkendeng.
\end{abstract}

Kata Kunci: Analisis Framing, Media Berita Online, Ideologi, Media Baru, Konflik Semen Kendeng 


\section{Pendahuluan}

Rencana pendirian pabrik semen di kawasan pegunungan kapur Kendeng, Kabupaten Pati dan Kabupaten Rembang, Jawa Tengah, mendapat berbagai perlawanan warga kendeng penolak pendirian pabrik semen. Konflik bermula pada tahun 2006 oleh warga Sukolilo yang dikenal sebagai penganut ajaran Samin menolak keras rencana studi eksplorasi untuk pendirian pabrik semen oleh PT Semen Gresik (PT Semen Indonesia) di Kecamatan Sukolilo, Kabupaten Pati, Jawa Tengah. Warga yang menolak lewat Jaringan Masyarakat Peduli Pegunungan Kendeng (JMPPK) lalu mengajukan gugatan ke PTUN Semarang untuk mencabut studi eksplorasi ini dan menang, kemudian PT Semen Indonesia melakukan banding ke Pengadilan Tinggi Negeri Surabaya dan menang, hingga JMPPK banding lagi ke Mahkamah Agung (MA) pada pertengahan 2009 dan menang, sementara PT Semen Indonesia sudah memutuskan untuk keluar sebelum ada keputusan MA. Akhirnya, PT Semen Indonesia sebagai perusahaan milik BUMN (Badan Usaha Milik Negara) memutuskan membangun pabrik di Tuban pada tahun 2009 dan kemudian tahun berikutnya mendirikan satu pabrik lagi masuk ke lokasi baru pembangunan pabrik semen di Desa Tegaldowo, Kecamatan Gunem, Kabupaten Rembang, Jawa Tengah yang memulai peletakan batu pertama pendirian pabrik semen pada 16 Juni 2014. Sebagian warga Gunem yang kontra pendirian pabrik melakukan pemblokiran jalan menuju lokasi tambang sehingga menimbulkan kericuhan masyarakat yang sebagian besar ibuibu dengan aparat Kepolisian dan TNI yang menjaga lokasi. Aksi tuntutan penolakan pabrik semen berlanjut dengan mendirikan tenda dan menggelar doa bersama di tapak pabrik.

Laporan penelitian Pusat Studi Keamanan dan Perdamaian (PSKP) UGM (2015) menyebutkan perbedaan kepentingan ini kemudian menimbulkan konflik yang berkepanjangan dari tahun 2012-2015 antara PT Semen Indonesia dengan masyarakat yang tergabung dalam JMPPK. Semenjak dimulainya
PT Semen Indonesia yang mendirikan pabrik di wilayah perhutani pegunungan kendeng, Kecamatan Bulu, pada tahun 2012, eskalasi konflik mengalami beberapa tahapan konflik selama tiga tahun. Konflik tahap I di tahun 20122014 masih dalam kondisi laten yang nampak di masyarakat Desa Tegaldowo dengan adanya perpecahan antara masyarakat yang pro dan yang kontra (menolak) terhadap pembangunan pabrik PT Semen Indonesia. Konflik tahap II terjadi pada 15 Juni 2014 dengan munculnya aksi terbuka perlawanan warga yang tergabung dalam JMPPK dengan pemblokiran jalan akses masuk ke pabrik semen oleh kurang lebih 20 perempuan. Beberapa bulan kemudian tepatnya pada 26-27 September 2014 dapat disebut sebagai konflik tahap III dengan munculnya aksi sebagai eskalasi krisis dimana aksi dilakukan tidak hanya dengan penghadangan semata tetapi juga disertai dengan alat bambu runcing dan lesung sebagai simbol petani. Kini warga Pati dan Rembang dibantu orangorang Samin yang tergabung dalam Jaringan Masyarakat Peduli Pegunungan Kendeng (JMPPK) menghadapi PT Semen Indonesia di Rembang dan PT Indocement di Kecamatan Kayen dan Tambakromo, Pati, Jawa Tengah. Pro dan kontra masyarakat dalam menyikapi konflik tersebut tidak terlepas dari peranan media massa dalam membentuk dan mengkonstruksinya. Namun, realitanya media tidak memberikan informasi yang utuh, tidak proporsional, parsial dan lebih menunjukkan keberpihakan pada salah satu pihak saja dalam memberitakan konflik. Sementara masyarakat membutuhkan berita-berita yang objektif agar dapat melihat akar permasalahan secara utuh dan realitas apa sebenarnya yang terjadi. Peliputan berita yang tak berimbang hanya akan memperuncing konflik yang terjadi. Media bukan lagi sekadar saluran yang bebas, ia juga subjek yang mengkonstruksi realitas, lengkap dengan pandangan, bias, dan pemihakannya (Eriyanto, 2012). Lewat medialah, ideologi dominan mengenai apa yang baik dan apa yang buruk yang disebarkan, 
itu dimapankan. Karena media membantu kelompok dominan menyebarkan ide atau gagasannya, mengontrol kelompok lain, dan membentuk konsensus antar anggota komunitas (Barrat, 1994). Hal demikian tercermin pada berita-berita yang menceritakan kemenangan kelompok (untuk memompa semangat), diinjakinjaknya harga diri kelompok mereka oleh kelompok lawan (untuk memunculkan simpati), serta cerita-cerita human interest yang muaranya adalah membentuk solidaritas kelompok. Upaya untuk mengetahui kecenderungan pemberitaan itu dapat dilakukan dengan melalui berbagai cara. Biasanya penelitian yang mengeksplorasi tentang kebijakan redaksional ini lebih banyak melihat isi media massa dengan metode analisis isi (content analysis) dan analisis bingkai (framing analysis). Dalam artikel ini penulis menggunakan analisis framing khususnya pada media berita online. Kehadiran media berita online dalam dunia jurnalisme seiring dengan pesatnya perkembangan teknologi komunikasi dan pertumbuhan pengguna internet di Indonesia. Dibandingkan dengan media konvensional, media berita online jauh lebih unggul dalam hal kecepatan pemberitaan yang dapat diakses oleh penggunanya dimana saja dan kapan saja. Tetapi isu keunggulan ini kemudian menjadi masalah pokok dalam dunia jurnalisme online yaitu masalah kualitas dan kredibilitas informasi yang sampai ke masyarakat karena mengejar kecepatan menyampaikan informasi.

Media berita online yang menjadi kajian bagi penulis atas pemberitaan konflik pabrik semen di pegunungan Kendeng, Kabupaten Pati dan Kabupaten Rembang, Jawa Tengah adalah media berita online nasional kompas.com dan media berita online lokal suaramerdeka.com. Kompas.com dipilih dengan pertimbangan sebagai media berita online nasional dengan intensitas pemberitaan pabrik semen kendeng lebih banyak dibandingkan dengan media berita online nasional lainnya dan memiliki wartawan atau kontributor sendiri di wilayah Semarang, Jawa Tengah, serta berada pada peringkat 11 top sites di Indonesia versi alexa.com. Perbandingan pencarian keyword dan peringkat situs beberapa media berita online nasional yang diambil pada 29 Februari 2016 seperti tergambar pada tabel di bawah.

Sementarasuaramerdeka.commerupakan media berita online lokal di Jawa Tengah dan memiliki peringkat top site di Indonesia lebih tinggi dibandingkan dengan situs media berita online lokal lainnya. Dari permasalahan tersebut, maka rumusan masalah dalam penelitian ini berfokus pada bagaimana media berita online kompas.com dan suaramerdeka.com membingkai berita konflik pabrik semen kendeng? Konflik pabrik semen kendeng seperti halnya konflik-konflik sosial lainnya di Indonesia dan di dunia, tentu memiliki penyebab yang bisa dijelaskan dengan rangkaian teori tertentu. Untuk itu diperlukan sebuah kerangka pemikiran di mana pemahaman mengenai teori tersebut akan membawa kesimpulan tentang apa yang harus dilakukan untuk menangani konflik, bahkan dalam skala lebih luas pemahaman itu akan menjadi pedoman untuk membuat kebijakan dalam rangka mencegah terjadinya konflik dalam eskalasi tertentu di masa mendatang. Konflik sendiri menurut

Tabel 1. Pencarian Keyword dan Peringkat Situs Beberapa Media Berita Online Nasional

\begin{tabular}{|l|l|l|l|l|}
\hline \multicolumn{1}{|c|}{ Media } & $\begin{array}{c}\text { Keyword } \\
\text { "Pabrik Semen } \\
\text { Kendeng" }\end{array}$ & $\begin{array}{c}\text { Keyword } \\
\text { "Pabrik } \\
\text { Semen Pati" }\end{array}$ & $\begin{array}{c}\text { Keyword } \\
\text { "Pabrik } \\
\text { Semen } \\
\text { Rembang" }\end{array}$ & $\begin{array}{c}\text { Peringkat } \\
\text { Situs di } \\
\text { Indonesia } \\
\text { versi } \text { alexa. } \\
\text { com }\end{array}$ \\
\hline Kompas.com & 6.444 berita & 7.185 berita & 6.692 berita & 11 \\
\hline Tempo.co & 104 berita & 189 berita & 56 berita & 33 \\
\hline Detik.com & 17 berita & 52 berita & 53 berita & 5 \\
\hline
\end{tabular}


Galtung (2007) berasal dari confligere yang berarti 'saling mengejutkan'. Dalam pengertian sederhana, konflik sebagai hubungan antara dua atau lebih (individu atau kelompok) pihak yang berpikir memiliki tujuan tidak sejalan. Sementara konflik dalam definisi Putnam (2006) dikatakan sebagai sebuah perselisihan yang termanifestasikan dalam bentuk konfrontasi fisik atau non-fisik antara beberapa pihak dalam arena distribusi sumberdaya yang terbatas. Sedangkan Susan (2009) memiliki asumsi dasar mengenai teori konflik yaitu pertama, setiap individu mempunyai kepentingan (interest) yang berbeda, bahkan bertentangan dengan individu atau kelompok lain di dalam suatu masyarakat. Yang kedua, sekelompok orang mempunyai kekuatan yang lebih dibandingkan kelompokkelompok lainnya. Dan yang ketiga, kepentingan dan penggunaan kekuatan untuk mencapai kepentingan tersebut dilegitimasi dengan sistem ide dan nilai-nilai yang disebut dengan ideologi.

Terlepas dari posisi epistemologi konflik itu sendiri merupakan salah satu news value sebuah peristiwa, yang selalu berhasil menarik media untuk meliputnya. Asumsinya, ada pola yang terekam dalam berita-berita konflik itu secara bertahap dapat dipahami dengan membahas tentang perspektif dan teori yang digunakan dalam melihat berita konflik, untuk kemudian menjelaskan landasan konseptual tentang bagaimana konstruksi sosial muncul dalam situasi tersebut. Berita yang tersaji di media adalah produk dari interaksi wartawan dengan fakta. Realitas media massa merupakan realitas pengamatan kedua, sebagaimana yang dikatakan oleh Berger and Luckmann (2000) bahwa, "The reality of the mass media is the reality of second-order observation. It replaces knowledge prescriptions which have been provided in other social formations by excellent positions of observation: by sages, priest, the nobility, the city, by religion or politically and ethically distinguished ways of life".

Penggambaran yang dilakukan oleh media massa tentu saja bukanlah realitas peristiwa itu sendiri, karena itu tidak bisa disamakan antara realitas dunia nyata peristiwa dengan apa yang diberitakan oleh media massa. Fiske dalam Sulhan (2006) memberikan penggambaran terkait bagaimana menghadirkan sebuah berita oleh seorang wartawan ke dalam tiga level. Yaitu, level pertama, terjadi peristiwa yang ditandakan (encode) sebagai realitas. Bagaimana peristiwa itu dikonstruksi sebagai realitas oleh wartawan media. Dalam bahasa gambar (khususnya televisi) hal ini selalu berhubungan dengan aspek-aspek konkret semisal pakaian, lingkungan, ucapan, dan ekspresi. Di sini, realitas selalu siap ditandakan, ketika kita menganggap dan mengkonstruksi peristiwa tersebut sebagai realitas. Pada level kedua, ketika kita memandang sesuatu sebagai realitas, pertanyaan berikutnya adalah bagaimana realitas itu digambarkan. Disini kita menggunakan perangkat secara teknis. Dalam bahasa tulis, alat teknis itu adalah kata, kalimat atau proposisi, grafik, dan sebagainya. Dalam bahasa gambar, alat itu berupa kamera, pencahayaan, editing, atau musik. Pemakaian kata-kata, kalimat, atau proposisi tertentu akan membawa suatu makna tertentu pula ketika diterima oleh khalayak. Level ketiga, pada tataran berikutnya adalah bagaimana peristiwa tersebut diorganisir ke dalam konvensikonvensi yang diterima secara ideologis.

Untuk dapat mengungkap rahasia dibalik sebuah perbedaan bahkan pertentangan media dalam mengungkapkan fakta serta bagaimana mengetahui realitas yang dibingkai oleh media, dalam tulisan ini penulis menggunakan analisis framing model Entman. Secara esensial, framing yang dilihat oleh Entman (1993) mengandung dua unsur utama yaitu seleksi dan penonjolan. Penonjolan atau penekanan kata itu sendiri adalah proses-proses membuat informasi menjadi lebih bermakna, lebih menarik, berarti, atau lebih diingat oleh khalayak. Dalam konsepsi mengenai framing, Entman (1993, 2007) membaginya ke dalam empat elemen, yaitu: 1) Define Problems (pendefinisian masalah), 2) Diagnose Causes (pendiagnosisan penyebab), 3) Make Moral Judgements (penilaian moral), dan 4) Suggest Remedies (solusi). 
Jika dilihat dari perspektif komunikasi, analisis framing mengarah kepada sebuah metode analisis media yang dipakai untuk membedah cara-cara atauideologimediasaatmengkonstruksi fakta. Sehingga hasil dari pembingkaian tersebut dapat diketahui bahwa media lebih berpihak kepada siapa (apakah seorang tokoh, salah satu kelompok tertentu atau golongan). Secara positif istilah ideologi dipersepsi sebagai suatu pandangan dunia yang menyatakan nilai-nilai suatu kelompok sosial tertentu untuk membela dan memajukan kepentingan-kepentingan mereka. Sedangkan secara negatif, ideologi dilihat sebagai kesadaran palsu, yaitu suatu kebutuhan untuk melakukan penipuan dengan cara memutarbalikkan pemahaman orang mengenai realitas sosial (Sobur, 2015). Tidak salah bila media menjadi tempat pertarungan ideologi antara kelompok-kelompok yang ada di masyarakat, karena media dipandang sebagai instrumen ideologi melalui kelompok yang menyebarkan pengaruh dan dominasinya kepada kelompok lain. Secara tidak sadar, ideologi kelompok dominan yang mendapatkan tempat dan dimapankan dalam pemberitaan. Dengan cara ini, tindakan, perbuatan atau ucapannya sebetulnya telah dikontrol dengan jalan tertentu untuk mendukung gagasan atau tindakan tertentu yang tidak disadari oleh orang (Eriyanto, 2002).

\section{Metode Penelitian}

Penelitian ini merupakan penelitian kualitatif deskriptif dengan menggunakan analisis isi media melalui teknik analisis framing. Untuk dapat menerapkan analisis framing dalam melihat bagaimana konstruksi yang dilakukan oleh media berita online kompas. com dan suaramerdeka.com dalam membingkai berita konflik pabrik semen, maka salah satu model yang digunakan dalam penelitian ini adalah model framing yang dikembangkan oleh Robert M. Entman. Ada empat elemen utama dalam framing yang ditawarkan oleh Entman, yaitu: Define Problems (pendefinisian masalah), Diagnose Causes (pendiagnosisan penyebab), Make Moral Judgements (penilaian moral), dan Suggest Remedies (solusi). Namun, dalam penelitian ini hanya elemen define problems dan diagnose causes yang digunakan oleh penulis agar fokus melihat bagaimana peristiwa konflik dimaknai oleh wartawan dan untuk menunjukkan posisi serta keberpihakan media.

Sampel dalam penelitian ini adalah keseluruhan berita mengenai konflik yang terjadi pada pendirian pabrik semen yang dimuat di media berita online kompas.com dan suaramerdeka. com pada kurun waktu tahun 2015. Pemilihan pada rentang waktu tahun 2015 itu didasarkan atas pertimbangan bahwa terjadinya perseteruan pendirian pabrik semen dengan masyarakat menarik banyak user/pengunjung/pembaca media berita online, mulai dari masyarakat umum, akademisi, LSM, sampai lembaga pemerintahan.

Berita yang telah dikategorikan dengan kriteria yang terkait berita konflik pendirian pabrik semen kendeng di Kabupaten Pati dan Kabupaten Rembang, Jawa Tengah, sebanyak 25 topik berita yang diambil di kompas.com dan 30 topik berita yang diambil di suaramerdeka.com. Alasan memilih obyek ini, Pertama, konflik pabrik semen merupakan konflik kepentingan yang rentan terjadi di Indonesia dan selalu berulang. Kedua, pemberitaan konflik di media online kian menjadi kecenderungan baru yang kolektif dan menjadi sarana baru bagi kelompokkelompok tertentu untuk berkomunikasi dan menyalurkan pendapatnya terkait persoalan yang terjadi di masyarakat, termasuk diantaranya konflik pendirian pabrik semen kendeng. Ketiga, penelitian lebih khusus terhadap kompas.com dan suaramerdeka.com untuk melihat fenomena konflik pabrik semen dibingkai dalam berbagai liputan seperti hardnews, softnews, sertafeatures, baik skala nasional maupun lokal. Kompas.com dipilih sebagai media berita online nasional yang memberitakan permasalahan pendirian pabrik semen kendeng dengan intensitas pemberitaan lebih banyak dibandingkan dengan media berita online nasional lainnya. Sedangkan dipilihnya suaramerdeka.com sebagai media berita online lokal dengan slogannya "Perekat Komunitas Jawa Tengah" yang mencerminkan 
posisi dari media ini dan merupakan divisi usaha dari Suara Merdeka Group yang bergerak di bidang pemberitaan online.

Sumber data primer dari penelitian ini didapatkan dengan mengumpulkan semua berita-berita tentang konflik pabrik semen kendeng yang dimuat dalam media berita online kompas.com dan suaramerdeka.com pada kurun waktu tahun 2015. Untuk mendapatkan kedalaman makna dari hasil temuan analisis framing, maka dilengkapi dengan sumber data sekunder yang diperoleh dari hasil wawancara mendalam dengan PT. Semen Indonesia (persero) Tbk., wartawan/kontributor Semarang kompas.com dan wartawan suaramerdeka.com. Data sekunder lainnya diperoleh dari bukubuku ilmiah, hasil penelitian, dan jurnal yang relevan dengan topik penelitian ini, serta sumber referensi lainnya dari pencarian di internet.

\section{Hasil dan Pembahasan}

Untuk melihat framing dan ideologi media pada kompas.com dan suaramerdeka. com, penulis membaginya ke dalam tiga kategori yaitu pertama, aksi perjuangan warga Kendeng, kedua, sidang gugatan pabrik semen kendeng, dan ketiga, peran Gubernur Jawa Tengah meredam konflik semen kendeng. Pemilihan kategori ini untuk melihat bagaimana pola framing kompas.com dan suaramerdeka.com yang diharapkan mampu menggambarkan framing pemberitaan konflik pabrik semen kendeng.

\section{Framing Kompas.com: Konsistensi Perlawanan}

1) Aksi Perjuangan Warga Kendeng. Sepak terjang warga Kendeng dalam melawan pendirian pabrik semen senantiasa terekam dalam pemberitaan kompas.com dan dianggap sebagai konsistensi perlawanan warga Kendeng yang menolak pabrik semen. Media ini seakan memperlihatkan perlawanan warga menolak pabrik semen perlu diakomodir dan disuarakan. Ini terlihat pada pemberitaannya yang lebih banyak membahas aksi dukungan dan perlawanan yang dilakukan oleh warga Kendeng serta pemilihan sumber berita dari satu pihak tertentu lebih menonjol dibandingkan dengan pihak lain. Media kompas.com memberi contoh konkret dalam topik berita berjudul "Jelang Putusan Izin Pabrik Semen, Warga Jalan Kaki 122 Km ke Semarang” pada tanggal 16 November 2015 secara jelas wartawan mengkonstruksi aksi warga jalan kaki sebagai rencana aksi simpatik warga penolak pabrik semen Pati. Sumber berita yang dihadirkan dalam berita adalah tokoh warga Sedulur Sikep Pati yang menjadi aktor aksi dan melihat aksi jalan kaki secara positif.

Sisi lain perjuangan masyarakat Kendeng penolak pabrik semen dimunculkan secara positif dalam topik berita tanggal 18 November 2015 berjudul "Ketika Tangis Warga Tapak Semen Luluhkan Hakim" yang membuat sadar para pihak bahwa pemerintah tak selamanya bisa memaksakan kuasanya kepada rakyat terutama hakim dalam memutuskan perkara melalui nuraninya dengan melihat sisi lain perjuangan warga Kendeng.

Begitu pula pada topik berita berjudul "Kalah di Pengadilan Tinggi, Walhi Siapkan Memori Kasasi Semen Rembang" pada tanggal 17 Desember 2015 yang memperlihatkan upaya perlawanan warga Rembang yang tidak berhenti meski mengalami nasib kalah di dua pengadilan. Isi berita ini membahas persoalan pengajuan memori kasasi Yayasan Walhi dan temuan barunya terkait kegagalan menggugat izin lingkungan PT Semen Indonesia di Rembang yang kandas baik di tingkat PTUN maupun pengadilan tinggi. Salah satu bahan yang diajukan ke tingkat Mahkamah Agung, seperti yang dikutip berita ini melalui sumber berita dari Muhnur Sathayaprabu (kuasa hukum warga yang juga manajer Kebijakan dan Pembelaan Hukum Walhi) adalah masalah lahan pengganti di Kendal yang bermasalah karena masih digunakan warga untuk bercocok tanam. Sementara itu, 
di bagian lain berita ini juga mengungkap kembali alasan putusan hakim yang menolak gugatan warga Rembang dan Yayasan Walhi untuk menghentikan pendirian pabrik semen Indonesia di Rembang. Permasalahan yang ditunjukkan oleh media ini nampak jelas dari judul beritanya. Akibat gugatan izin lingkungan PT Semen Indonesia di Rembang kalah di Pengadilan Tinggi dan juga pengadilan sebelumnya di PTUN Semarang, mengakibatkan Yayasan Walhi menyiapkan pengajuan memori kasasi semen Rembang. Penyebab tersebut seperti dalam kutipan dari sumber berita ini yang mengatakan putusan di pengadilan tinggi menguatkan putusan sebelumnya. Akhirnya, kegagalan ini menjadikan pihak warga Rembang dan Yayasan Walhi mengajukan kasasi ke Mahkamah Agung. Kesimpulan dari bingkai berita ini adalah meskipun kompas.com mengungkap temuan baru atas izin lingkungan PT Semen Indonesia dari rencana Yayasan Walhi yang mengajukan memori kasasi ke Mahkamah Agung, namun secara implisit hakim tetap memenangkan PT Semen Indonesia untuk tetap beroperasi membangun pabrik semen di Rembang.

Kompas.com sebagai media berita online nasional dengan frame humanisme-nya memiliki kecenderungan mengakomodir suara perlawanan warga Kendeng yang menolak pabrik semen. Aksi perjuangan warga Kendeng dilihat sebagai konsistensi perlawanan warga Kendeng menolak pabrik semen yang tidak melanggar asas kepatutan. Sebagaimana yang dikatakan oleh Nurdin (2016) bahwa keberpihakannya adalah apa yang mereka lakukan itu disuarakan, meski keberpihakannya tidak mencolok. "Masingmasing pihak sama-sama mempunyai argumen dan tugas saya apa yang disampaikan masing-masing pihak saya tulis, tetapi saya sendiri memihak. Apa yang diperjuangkan oleh mereka mencari yang terbaik itu yang muncul asal tidak melanggar asas kepatutan saja," (Nurdin, 2016).

\section{2) Sidang Gugatan Pabrik Semen}

Kendeng. Media berita online kompas. com melihat sidang gugatan pabrik semen kendeng sebagai putusan hakim menangkan warga Pati dan menolak warga Rembang. Ini terlihat pada sebagian besar pemberitaan mengenai sidang gugatan lebih banyak pembahasannya kepada hakim PTUN Semarang yang menangani kasus konflik semen kendeng. Dalam pemberitaan "Sidang 7,5 Jam, Hakim Akhirnya Menangkan Warga Pati soal Pabrik Semen" pada tanggal 17 November 2015 cukup jelas mendefinisikan hakim memutuskan kemenangan warga Pati dalam sidang nonstop 7,5 jam. Untuk menguatkan keputusan majelis hakim PTUN Semarang yang memenangkan gugatan warga Pati, media ini memberitakannya dengan judul "Izin Bupati Pati soal Semen Batal demi Hukum" pada 17 November 2015 yang menegaskan kembali putusan hakim membatalkan izin Bupati Pati batal demi hukum dan wajib dicabut. Begitu juga pada putusan hakim menolak gugatan warga Rembang dalam pemberitaan pada tanggal 16 April 2015 berjudul "Hakim Putuskan PT Semen Indonesia Tetap Beroperasi di Rembang” tampak jelas persoalan utama yang ingin ditekankan dalam berita ini adalah persoalan hakim telah memutuskan untuk menolak gugataan warga Rembang dan PT Semen Indonesia tetap beroperasi di Rembang. Dan untuk menguatkan putusan hakim, dalam pemberitaan pada tanggal yang sama 16 April 2015 dengan judul "Ini Alasan Hakim Tolak Gugatan Warga Rembang soal Pabrik Semen” sebagai penguatan atas alasan hakim PTUN Semarang menolak gugatan warga Rembang yang menurut media ini tidak perlu dibahas lebih lanjut karena sudah cukup jelas tenggang waktu gugatan telah kedaluarsa. Sumber berita yang menjadi pemberitaan tersebut dikutip dari pihak ketua hakim PTUN Semarang. Berita ini merupakan kelanjutan dari berita sebelumnya mengenai putusan hakim yang menolak gugatan warga Rembang dan 
Walhi terhadap pendirian pabrik semen di Rembang. Isi berita ini lebih menekankan alasan dari hakim menolak gugatan warga Rembang terkait pabrik semen karena pertimbangan gugatan telah kadaluarsa dan tidak lagi perlu mempertimbangkan alasan lainnya. Sehingga kegiatan pendirian pabrik semen Indonesia di Rembang tetap dilakukan. Bahkan, untuk kompas.com juga menyertakan running news atau tautan link berita sebelumnya untuk menguatkan lagi mengenai putusan hakim yang menolak gugatan warga.

Selain menjadikan ketua majelis hakim sebagai sumber berita, dalam berita ini juga menjadikan pihak penggugat yang ditolak oleh hakim sebagai sumber berita dengan mengatakan bahwa alasan penolakan gugatan warga Rembang oleh majelis hakim tidak begitu jelas batas waktu kedaluarsanya atau waktu 90 hari setelah SK Gubernur diumumkan dan tidak memeriksa pokok perkaranya. Meskipun media ini juga mengurai penilaian dari kuasa hukum penggugat, tetap saja penekanannya adalah pada alasan hakim yang menolak gugatan warga baik terlihat pada judul berita maupun pada lead berita.

Adanya batas waktu gugatan yang diajukan telah kedaluarsa menjadi penyebab persoalan dari alasan hakim memutuskan menolak gugatan warga Rembang beserta Yayasan Wahana Lingkungan Hidup Indonesia soal pabrik semen. Inilah yang menjadikan majelis hakim sebagai aktor atau pelaku dalam berita ini. Sehingga, kesimpulan dari bingkai berita ini adalah alasan hakim PTUN Semarang menolak gugatan warga Rembang tidak perlu dibahas lebih lanjut karena sudah cukup jelas tenggang waktu gugatan telah kedaluarsa.

3) Peran Gubernur Jawa Tengah Meredam Konflik Semen Kendeng. Bingkai kompas.com melihat peran Gubernur Jawa Tengah ini sebagai mediator konflik warga penolak pabrik semen. Terlihat dari pemberitaan mengenai Ganjar Pranowo, Gubernur Jawa Tengah yang memposisikannya sebagai penengah polemik antara warga penolak pabrik semen dengan Pemerintah Kabupaten Pati dan semen. Dalam pemberitaan "Ganjar: Demo Boleh, tetapi Jangan Sampai Tutup Jalan” tanggal 4 Agustus 2015 menggambarkan sosok Gubernur sebagai pihak penengah yang tidak memihak siapapun dan memenuhi aspirasi warga penolak pabrik semen Pati mempertemukannya dengan Bupati Pati.

Dalam berita ini Gubernur mengungkapkan bahwa kebebasan berpendapat memang dilindungi oleh konstitusi, namun Gubernur meminta kepada warga penolak pabrik semen Pati untuk tidak anarkis dengan menutup jalan dan memblokir jalan pantura karena itu merupakan tindakan pidana. Media ini selain mengungkapkan permintaan Gubernur dalam audiensi dengan puluhan warga Tambakromo, Pati yang menolak pendirian pabrik semen, juga menyatakan bahwa dirinya bukanlah dipihak semen maupun pihak kontra semen. Seperti yang dikutip kompas.com melalui sumber berita Ganjar Pranowo, Gubernur Jawa Tengah yang mengatakan bahwa dirinya ingin mendudukkan masalah ini dengan akal sehat.

Supaya berimbang, kompas.com juga mengutip sumber lain dari warga penolak pabrik semen Pati yang hadir dalam audiensi yang mengatakan kehadirannya sengaja untuk menemui Gubernur guna mengadukan Bupati Pati yang tidak mau mendengar aspirasi warga Pati terkait rencana pendirian pabrik semen di kawasan gunung Kendeng dan meminta Gubernur mengunjungi desanya serta memfasilitasi pertemuan dengan Bupati Pati.

Adanya permintaan Gubernur Jawa Tengah, Ganjar Pranowo disebabkan atas tindakan anarkis warga Pati penolak pabrik semen selaku aktor penyebab masalah. Mengutip pernyataan Gubernur Jawa Tengah dalam berita ini yang dulunya juga sering demo dan sekarang gantian di demo warga. Terkait kekhawatiran akan pendirian pabrik semen, warga dipersilakan untuk menyampaikan unegunegnya dengan cara baik dan mengawal proses gugatan yang sedang berlangsung. Gubernur juga berjanji untuk mengkomunikasikan 
aspirasi warga untuk bertemu dengan Bupati Pati. Dengan demikian, bingkai dari berita ini adalah Gubernur digambarkan sebagai pihak yang tidak memihak siapapun dan berjanji untuk memenuhi aspirasi warga penolak pabrik semen Pati mempertemukannya dengan Bupati Pati.

Begitu pula pada topik berita berjudul "Janji Ganjar, Bupati, dan Warga Penolak Pabrik Semen...” pada tanggal 13 Agustus 2015 dipahami sebagai janji Gubernur Jawa Tengah, Ganjar Pranowo untuk mempertemukan warga penolak pabrik semen Pati dengan Bupati Pati, Haryanto akhirnya terwujud dalam satu forum diskusi di Pendopo Kabupaten Pati. Disebutkan dalam berita ini, permasalahan yang diperbincangkan mengenai penerbitan dokumen dampak analisis lingkungan atau Amdal untuk izin kegiatan penambangan. Selain mengungkap keluh kesah warga penolak pabrik semen, juga mendengar jawaban dari Bupati Pati secara langsung. Namun, warga tetap saja tidak puas dengan jawaban dari Bupati. Janji Gubernur Jawa Tengah kepada warga Pati penolak pabrik semen untuk bertemu dengan Bupati Pati terkait masalah keluarnya dokumen Amdal dari Bupati Pati menjadi sebab terwujudnya pertemuan tersebut. Dalam berita ini Gubernur Jawa Tengah diposisikan sebagai pelaku sekaligus penengah dari penyebab masalah. Pertemuan antara warga dan Bupati Pati, dapat terjadi lantaran adanya perantara Gubernur Jawa Tengah yang oleh media ini dijelaskan untuk menengahi polemik konflik warga dan bupati dalam menemukan titik temu permasalahan. Bahkan kompas.com memberikan running news atau tautan link berita sebelumnya untuk memperkuat peran Gubernur Jawa Tengah dalam konflik warga penolak pabrik semen Pati dengan Bupati Pati. Secara khusus Gubernur meminta kepada Bupati Pati untuk terus mengajak dialog atau rembugan dengan warga. Secara keseluruhan, bingkai berita ini adalah peran Gubernur Jawa Tengah sebagai penengah mempertemukan warga penolak pabrik semen Pati yang berpolemik dengan Bupati Pati. Pengambilan tokoh sebagai sumber berita dalam pemberitaan merupakan kasus unik yang dapat menarik perhatian pembaca. Kasuskasus yang unik tersebut adalah kasus-kasus yang 'remeh temeh' melibatkan orang-orang besar, aktivis, yang media lain tidak ambil. Sebagaimana yang diungkap oleh Nurdin (2016) bahwa kasuskasus yang unik dari segi human interest-nya itu sangat laku di kompas online terutama berita dari daerah. Mencari sisi lain dari para tokoh dengan perspektif Jakarta dengan lokal karena versi orang Jakarta sama versi orang daerah berbeda.

\section{Framing Suaramerdeka.com: Religiusitas dan Kepegiatan}

1) Aksi Perjuangan Warga Kendeng. Media berita online lokal suaramerdeka. com melihat aksi perjuangan warga Kendeng dimaknai sebagai religiusitas warga pro semen dan kepegiatan warga kontra semen Kendeng. Ini terlihat dalam salah satu pemberitaannya tanggal 2 April 2015 berjudul "Pendukung Pabrik Semen Indonesia Gelar Doa Bersama di PTUN" tampak media ini membahas pendukung pendirian pabriksemendiRembang, sehingga keberpihakan terhadap satu pihak yaitu pro semen Rembang terlihat. Para pendukung pabrik semen Indonesia ini digambarkan dengan melakukan aksi doa bersama dan bersholawat di depan PTUN Semarang dalam rangka mengawal sidang gugatan ijin pendirian pabrik semen Rembang. Bagus, warga ring satu Tegaldowo, Rembang yang menjadi satu-satunya sumber berita ini, mengungkapkan bahwa keberadaan semen Indonesia terbukti bermanfaat dan dirinya mendukung 1000 persen pendirian pabrik semen karena terbukti warga Kendeng sudah merasakan manfaatnya dengan hidup damai dan sejahtera. Penyebab kedatangan ratusan massa pendukung pabrik semen Rembang adalah untuk mendukung keberadaan pendirian pabrik semen Indonesia di Rembang dalam sidang putusan PTUN Semarang terhadap izin pendirian pabrik semen Rembang. Selama aksi ini dilakukan, 
suaramerdeka.com menggambarkan warga Kendeng pendukung pabrik semen Indonesia tidak terprovokasi oleh oknum di luar warga Kendeng. Sehingga, bingkai dari berita ini adalah warga Kendeng pro semen Rembang mendukung penuh pendirian pabrik semen Rembang karena terbukti hidupnya damai dan sejahtera dengan adanya pabrik semen.

Begitu pula berita tanggal 16 April 2015 berjudul "Kelompok Pro Semen Rembang Gelar Doa Bersama" yang menggambarkan warga pro semen Rembang beraksi dengan memanjatkan doa dan melantunkan sholawatan. Sedangkan warga kontra semen Pati dalam judul pemberitaan "Tolak Pabrik Semen, Warga Jalan Kaki dari Pati ke Semarang” pada tanggal 17 November 2015 dikonstruksi bukan sebagai aksi yang mencari sensasi namun sebagai upaya warga Pati penolak pabrik semen Pati melakukan aksi jalan kaki dari Pati ke Semarang agar pemerintah memperhatikan aspirasi warga Pati. Digambarkan pula warga rela bekerja keras memeras keringat melakukan aksi jalan kaki dari Pati ke Semarang dengan harapan majelis hakim PTUN Semarang mengabulkan tuntutannya. Sumber berita yang dihadirkan dalam berita ini adalah Gunretno, koordinator JMPPK melihat aksi berjalan kaki juga secara positif.

Media suaramerdeka.com ini berusaha untuk menghindari pemberitaan konflik dengan memberitakan secara proporsional antara pro semen kendeng dan kontra semen kendeng. Dengan frame News Aktualnya mengakomodir semua elemen yang berkonflik baik yang berpihak pada semen, dan pihak yang kontra semen, maupun yang netral. Menurut Luhur (2016) apa yang mereka perjuangkan harus diungkap sesuai dengan wawancara yang ditulis, namun tetap harus proporsional mendengar dari pihak semen. sehingga ada sisi warga juga ada sisi semennya.

2) Sidang Gugatan Pabrik Semen Kendeng. Portal lokal suaramerdeka.com lebih mengungkap kemenangan warga Kendeng kebenaran Yang Maha Kuasa dan optimisme kubu Rembang. Kemenangan warga Kendeng merupakan keputusan dari majelis hakim PTUN Semarang yang dianggap sebagai kebenaran yang diberikan Yang Maha Kuasa karena berhasil mengungkap adanya manipulasi pelanggar Perda RTRW (Rencana Tata Ruang Wilayah) Kabupaten Pati. Sebagaimana terlihat dalam pemberitaan tanggal 17 November 2015 dengan topik berjudul "Warga Kendeng Menangkan Gugatan” dan topik berita tanggal 18 November 2015 berjudul "Putusan Majelis Hakim, Kebenaran dari Yang Maha Kuasa” yang sama-sama menggambarkan kemenangan masyarakat Kendeng yang sebelumnya pesimis bakal menang karena beranggapan pengadilan hanya milik orang berpunya. Oleh karena itu, kemenangan ini dianggap sebagai kebenaran dari Yang Maha Kuasa. Sayangnya, sumber berita yang diambil mengenai putusan hakim memenangkan gugatan warga bukan berasal dari sumber berita mengutip ketua majelis hakim namun mengutip dari sumber yang dilansir oleh media ini.

Sedangkan bingkai berita terkait semen Rembang cenderung menempatkan kedua kubu yang saling klaim optimis menang seperti tampak jelas dalam topik pemberitaan tanggal 5 April 2015 berjudul "Soal Izin Lingkungan Pabrik Semen, Dua Kubu Optimis Menang”. Judul berita dan lead berita dengan jelas melihat permasalahan dua kubu yaitu antara Walhi selaku penggugat dan kubu tergugat II PT Semen Indonesia yang sama-sama saling klaim optimis bakal menang. Di sini media suaramerdeka.com secara proporsional memberitakannya dengan mengutip sumber berita dari kedua belah pihak. Media ini menjelaskan dengan mengutip kedua belah pihak sebagai sumber berita, bahwa dalam perkara ini, pihak Walhi meminta SK Gubernur Jateng Nomor 668.1/17 Tahun 2012 tentang Izin Lingkungan Kegiatan Penambangan oleh PT Semen Gresik (Persero) Tbk di Kabupaten Rembang supaya dicabut. Sedangkan di pihak PT Semen Indonesia menilai langkah penggugat yang melapor ke Komisi Yudisial untuk mengintervensi hakim merupakan sikap frustasi 
di luar hukum. Persoalan izin lingkungan pabrik semen yang menjadi penyebab terjadinya kedua kubu sekaligus oleh media ini diposisikan sebagai aktor penyebab saling klaim optimis bakal memenangkan gugatan di PTUN Semarang. Dalam sidang terakhir, Walhi menyerahkan 130 halaman kesimpulan berikut lampiran atas gugatannya. Sedangkan PT Semen Indonesia menyerahkan 136 halaman kesimpulan serta ratusan lembar lampirannya. Bingkai berita ini adalah saling klaim bakal menangkan gugatan antara Walhi dan PT Semen Indonesia.

3) Peran Gubernur Jawa Tengah Meredam Konflik Semen Kendeng. Dalam melihat peran Gubernur Jawa Tengah meredam konflik semen Kendeng, media ini memaknai peran Gubernur Ganjar dengan penuhi janji warga penolak pabrik semen, yaitu janji meninjau lokasi tapak pabrik semen yang akan dijadikan lokasi pembangunan pabrik semen Pati. Ini terlihat dalam pemberitaan "Gubernur Cek Tapak Pabrik Semen Pati" pada tanggal 5 November 2015 yang membingkai Gubernur sebagai sosok pejabat yang memenuhi janjinya kepada warga. Berita ini menceritakan masalah pemenuhan janji yang ditepati oleh Gubernur Jawa Tengah, Ganjar Pranowo kepada warga Pati untuk melihat secara langsung lokasi rencana dijadikan tapak pabrik semen PT Sahabat Mulia Sakti (SMS) di Kabupaten Pati. Dalam kerumunan warga penolak pabrik semen, Gubernur digambarkan oleh media ini memberikan penjelasan kepada warga yang hadir mengenai tapak pabrik semen yang akan dijadikan lokasi pendirian pabrik semen. Di depan warga penolak pabrik semen Pati, Ganjar mempersilakan untuk mendirikan pabrik, namun dengan catatan harus memenuhi persyaratan dan masyarakat diajak berembug dalam prosesnya. Media ini juga mengutip pernyataan tokoh setempat Gunretno yang menyatakan PT SMS berencana mendirikan pabrik semen di empat desa dan penolakan pabrik semen di kawasan karst adalah harga mati.

Lead berita ini menerangkan penyebab dari tinjauan Gubernur Jawa Tengah ke lokasi tapak pabrik semen Pati, yaitu untuk memenuhi janjinya saat Ngopi Bareng Gubernur di Pendapa Pemkab Pati. Di sini gubernur digambarkan sebagai pejabat yang memenuhi janji kepada warga, sehingga media ini memposisikan Gubernur Jawa Tengah, Ganjar Pranowo sebagai pelaku penyebab masalahnya. Secara keseluruhan, bingkai berita ini adalah Gubernur Jawa Tengah memenuhi janji kepada warga Pati untuk meninjau langsung lokasi tapak pabrik semen yang dijadikan pabrik semen oleh PT SMS. Dalam isu konflik pabrik semen Rembang, penulis tidak melihat peran Gubernur dalam kasus konflik pabrik semen di Rembang.

\section{Simpulan}

Pemaknaan yang berbeda-beda dalam mengemas peristiwa konflik pendirian pabrik semen kendeng di media berita online nasional kompas.com dan media berita online lokal suaramerdeka.com tidak terlepas dari ideologi yang dianut oleh masing-masing media serta ideologi di tingkat kultur masyarakat Pati dan Rembang. Ideologi yang ditunjukkan oleh media beritaonlinenasional kompas.comlebihcenderung memberikan porsi lebih dominan kepada salah satu pihak yang berkonflik dengan nilai-nilai ideologi kelompok yang tercermin dalam tingkah laku kehidupan kesehariannya. Sementara media berita online lokal suaramerdeka.com relatif proporsional dalam memberitakan pihak pro dan kontra pabrik semen kendeng. Ideologi di tingkat kultur masyarakat, konteks kultur warga Samin yang berjuang melawan pendirian pabrik semen kendeng di wilayah Kabupaten Pati akan sangat berbeda dengan konteks kultur warga Rembang yang juga berjuang melawan pendirian pabrik semen kendeng di wilayah Kabupaten Rembang, Jawa Tengah. Warga Samin dikenal identik dengan sejarah perlawanan atau karakter 
keras kepalanya yang hidupnya hanya mengandalkan dari hasil pertanian karena ajaran budaya tidak memperbolehkan untuk berdagang, sementara warga Rembang dikenal identik dengan kelompok pesantrennya yang kuat sehingga sangat erat kaitannya dengan karakter religius masyarakatnya.

Catatan metodologis, konsep analisis framing model Robert M. Entman konteks konflik pabrik semen kendeng ini memiliki kelebihan pada aspek penekanan atau penonjolan bagaimana seorang wartawan mendefinisikan atau memahami sebuah realitas permasalahan konflik yang terjadi. Dari sini akan terlihat jelas di mana posisi keberpihakan media pada kelompok yang sedang bertikai. Namun, sepanjang menggunakan teori Entman ini khususnya pada elemen define problem yang masih terasa kelemahannya, penulis sering mengalami pemahaman yang berubah-ubah atau ambigu dalam mendefinisikan permasalahan konflik pabrik semen kendeng sehingga berdampak pada pemahaman pada elemen berikutnya. Aspek pemilihan fakta dan bagaimana isu/peristiwa konflik pabrik semen kendeng dipahami oleh wartawan juga menjadikan kelemahan konsep framing Entman ini karena tidak secara detail membahas mengenai bagaimana pemilihan fakta oleh wartawan itu ditekankan sehingga faktor kultural yang melatarbelakangi peristiwa konflik pabrik semen kendeng tidak nampak.

\section{Daftar Pustaka}

Barrat, David. (1994). Media Sociology. London and New York: Routledge.

Berger, Peter L., \& Luckmann, Thomas. (2000). The Social Construction of Reality: A Treatise in the Sociology of Knowledge. California: Stanford University Press.

Entman, Robert M. (1993). Framing: Toward Clarification of a Fractured Paradigm. Journal of Communication, 43(4), 51-58.

Entman, Robert M. (2007). Framing Bias: Media in the Distribution of Power. Journal of Communication, 57, 163-173.

Eriyanto. (2002). Analisis Framing: Konstruksi,
Ideologi, dan Politik Media (Maret 2011 ed.). Yogyakarta: LKiS Yogyakarta. Eriyanto. (2012). Analisa Wacana Pengantar Analisis Teks Media (II ed.). Yogyakarta: LKiS. Galtung, Johan. (2007). Introduction: peace by peaceful conflict transformation - the TRANSCEND approach. In C. W. a. J. Galtung (Ed.), Handbook of Peace and Conflict Studies. USA and Canada: Routledge.

Luhur, Puthut Ami. (2016). Wawancara Tentang Redaksi suaramerdeka. com dan Pemberitaan Konflik Pabrik Semen Kendeng. Semarang.: Wartawan suaramerdeka.com Desk Politik dan Pendidikan.

Nurdin, Nazar. (2016). Wawancara Tentang Redaksi kompas.com dan Pemberitaan Konflik Pabrik Semen Kendeng. Semarang, Jawa Tengah: Wartawan kompas.com Kontributor Semarang. PSKP-UGM. (2015). Laporan Penelitian Pusat Studi Keamanan dan Perdamaian (PSKP) UGM: Identifikasi Dan Analisis Pemetaan Data Kebutuhan Penanganan Daerah Paska Konflik Wilayah Kabupaten Rembang, Jawa Tengah. Yogyakarta: Universitas Gadjah Mada.

Putnam, Linda L. (2006). Definitions and Approaches to Conflict and Communication. The Sage Handbook of Conflict Communication: Integrating Theory, Research, and Practice, 1-32. Sobur, Alex. (2015). Analisis Teks Media: Suatu Pengantar untuk Analisis Wacana, Analisis Simiotik, dan Analisis Framing. Bandung: PT Remaja Rosdakarya. Sulhan, Muhamad. (2006). Dayak yang Menang Indonesia yang Malang Representasi Identitas Etnik Dayak di Media Massa. Yogyakarta: Fisipol UGM. Susan, Novri. (2009). Sosiologi Konflik dan Isu-Isu Konflik Kontemporer. Jakarta: Prenada Media Jakarta. 